\title{
Molecular and Cellular Diversity of Neuronal G-Protein-Gated Potassium Channels
}

\author{
Lev Koyrakh, ${ }^{1 \star}$ Rafael Luján, ${ }^{2 \star}$ Jose Colón, ${ }^{1}$ Christine Karschin, ${ }^{3}$ Yoshihisa Kurachi, ${ }^{4}$ Andreas Karschin, ${ }^{3}$ and \\ Kevin Wickman ${ }^{1}$ \\ ${ }^{1}$ Department of Pharmacology, University of Minnesota, Minneapolis, Minnesota 55455, 2Centro Regional de Investigaciones Biomédicas, Universidad de \\ Castilla-La Mancha, 02006 Albacete, Spain, ${ }^{3}$ Institute of Physiology, University of Würzburg, 97070 Würzburg, Germany, and ${ }^{4}$ Department of \\ Pharmacology II, Osaka University, Osaka 565-0871, Japan
}

Neuronal G-protein-gated potassium (GIRK) channels mediate the inhibitory effects of many neurotransmitters. Although the overlapping distribution of GIRK subunits suggests that channel composition varies in the CNS, little direct evidence supports the existence of structural or functional diversity in the neuronal GIRK channel repertoire. Here we show that the GIRK channels linked to GABA $\mathrm{B}_{\mathrm{B}}$ receptors differed in two neuron populations. In the substantia nigra, GIRK2 was the principal subunit, and it was found primarily in dendrites of neurons in the substantia nigra pars compacta $(\mathrm{SNc})$. Baclofen evoked prominent barium-sensitive outward current in dopamine neurons of the SNc from wild-type mice, but this current was completely absent in neurons from GIRK2 knock-out mice. In the hippocampus, all three neuronal GIRK subunits were detected. The loss of GIRK1 or GIRK2 was correlated with equivalent, dramatic reductions in baclofen-evoked current in CA1 neurons. Virtually all of the barium-sensitive component of the baclofen-evoked current was eliminated with the ablation of both GIRK2 and GIRK3, indicating that channels containing GIRK3 contribute to the postsynaptic inhibitory effect of $\mathrm{GABA}_{\mathrm{B}}$ receptor activation. The impact of GIRK subunit ablation on baclofen-evoked current was consistent with observations that GIRK1, GIRK2, and $\mathrm{GABA}_{\mathrm{B}}$ receptors were enriched in lipid rafts isolated from mouse brain, whereas GIRK3 was found primarily in higher-density membrane fractions. Altogether, our data show that different GIRK channel subtypes can couple to $\mathrm{GABA}_{\mathrm{B}}$ receptors in vivo. Furthermore, subunit composition appears to specify interactions between GIRK channels and organizational elements involved in channel distribution and efficient receptor coupling.

Key words: knock-out; mice; baclofen; hippocampus; substantia nigra; GABA

\section{Introduction}

The postsynaptic inhibitory effect of many neurotransmitters and drugs of abuse is mediated by G-protein-gated inwardlyrectifying potassium (GIRK/Kir3) channels (North, 1989; Luscher et al., 1997). GIRK channels are homotetrameric and heterotetrameric complexes (Inanobe et al., 1995, 1999; Kofuji et al., 1995; Krapivinsky et al., 1995a,b; Lesage et al., 1995; Wischmeyer et al., 1997). Three GIRK channel subunits (GIRK1-GIRK3) exhibit broad and overlapping distributions in the CNS, whereas the fourth subunit (GIRK4) is found primarily in the heart (Kobayashi et al., 1995; Krapivinsky et al., 1995a; Karschin et al., 1996; Chen et al., 1997). GIRK subunit knock-out mice exhibit overlapping but distinct cellular and behavioral phenotypes. Neuronal GIRK subunit ablation has been correlated with in-

Received Aug. 17, 2005; revised 0ct. 20, 2005; accepted 0ct. 20, 2005.

This work was supported by National Institutes of Health Grants MH61933 (K.W.), DA011806 (K.W.), and F32 HL074618-01 (L.K.), Consejería de Sanidad Junta de Comunidades de Castilla-La Mancha (JCCM) Grant SAN-04008-00 (R.L.), Educacion y Ciencia JCCM Grant PAI05-040 (R.L.), and Deutsche Forschungsgemeinschaft Grant SFB581 (A.K., C.K.). We thank Dr. Cheryl Marker for assistance with immunohistochemistry, Prof. Ryuichi Shigemoto for the generous gift of the anti-GABA $A_{B(1)}$ antibody, and Dr. Christian Lüscher for helpful discussions.

*L.K. and R.L. contributed equally to this work.

Correspondence should be addressed to Kevin Wickman, Department of Pharmacology, University of Minnesota,

6-120 Jackson Hall, 321 Church Street Southeast, Minneapolis, MN 55455. E-mail: wickm002@umn.edu. DOI:10.1523/JNEUROSCI.3484-05.2005

Copyright $\odot 2005$ Society for Neuroscience 0270-6474/05/2511468-11\$15.00/0 creased seizure propensity, hyperalgesia, blunted analgesia, and hyperactivity (Signorini et al., 1997; Blednov et al., 2001, 2003; Mitrovic et al., 2003; Marker et al., 2004, 2005).

The overlapping distributions of GIRK subunits in the CNS suggest that channels formed by multiple subunit combinations contribute to neuronal GIRK channel content. Most data, however, emphasize the role of GIRK2 in the formation of neuronal GIRK channels. For example, baclofen-evoked currents were significantly reduced in hippocampal, cerebellar, and midbrain dopamine neurons from GIRK2 knock-out (KO) mice (Luscher et al., 1997; Slesinger et al., 1997; Cruz et al., 2004). Because GIRK1 staining was dramatically reduced in GIRK2 KO mice (Liao et al., 1996; Signorini et al., 1997; Torrecilla et al., 2002), GIRK1/GIRK2 heteromultimers are widely considered the prototypical GIRK channel in the CNS.

Despite its broad distribution in the CNS, the functional relevance of GIRK3 is uncertain. Multiple groups have reported that GIRK3 expression either alone or with other GIRK subunits failed to yield functional GIRK channels (Kofuji et al., 1995; Lesage et al., 1995; Ma et al., 2002). Indeed, GIRK3 was shown to direct GIRK1/GIRK2 heteromultimers and GIRK2 homomultimers to lyzosomal degradation pathways, effectively reducing the number of functional GIRK channels on the cell surface (Ma et al., 2002). Other studies, however, have shown that recombi- 
nant GIRK3 forms functional channels with both GIRK1 and GIRK2, channels with biophysical and regulatory properties comparable with the well characterized cardiac GIRK channel (Jelacic et al., 1999, 2000). Furthermore, the complete loss of opioid-induced current in locus coeruleus neurons required the concurrent ablation of both GIRK2 and GIRK3 (Torrecilla et al., 2002). The relevance of GIRK3 to neuronal GIRK channels remains an interesting and important topic, particularly in light of the impact of GIRK3 ablation on drug reward behavior (Morgan et al., 2003).

Here, we explored multiple aspects of neuronal GIRK channel subunit composition and distribution. We tested the hypothesis that neuronal GIRK channels are postsynaptic signaling elements consisting of GIRK1 and GIRK2. We probed the validity of the channel-forming and -trafficking roles for GIRK3. Our findings highlight, among other things, the molecular diversity of GIRK channels in the brain and support a channel-forming role for GIRK3.

\section{Materials and Methods}

Animals. Animal use was approved by the Institutional Animal Care and Use Committee of the University of Minnesota. Efforts were made to minimize the pain and discomfort of the animals throughout the study.

Reagents. $R-(+)-\beta$-(Aminomethyl)-4-chlorobenzenepropanoic acid hydrochloride (baclofen) and $\left[S-\left(R^{\star}, R^{\star}\right)\right]$-[3-[[1-(3,4-dichlorophenyl) ethyl]amino]-2hydroxypropyl](cyclohexylmethyl) phosphinic acid (CGP54626) were purchased from Sigma (St. Louis, MO) and Tocris (Ellisville, MO), respectively. Rabbit anti-GIRK1, anti-GIRK2, and antiGIRK3 antibodies were obtained from Alomone Labs (Jerusalem, Israel). The rabbit anti-GABA $\mathrm{B}_{\mathrm{B}(\mathrm{la} / \mathrm{b})}$ antibody was described previously (LopezBendito et al., 2002). The affinity-purified guinea pig anti-vesicular glutamate transporter 1 (VGluT1) antibody was purchased from Chemicon (Temecula, CA).

In situ hybridization. Brains from three adult ( $8-10$ weeks of age) male wild-type (WT), GIRK1 KO, GIRK2 KO, and GIRK3 KO mice were frozen and sectioned. Sixteen-micrometer sections were fixed in PBS and $4 \%$ paraformaldehyde and stored in ethanol. Digoxigenin-labeled cRNA probes were prepared from GIRK cDNA fragments according to the manufacturer's protocol (F. Hoffmann-La Roche, Basel, Switzerland). The GIRK fragments spanned $\sim 500$ bp of $5^{\prime}$ coding sequence: rat Girk1 $\left(5^{\prime}\right.$-gacgatt ...tttcctc- $\left.3^{\prime}\right)$ and mouse Girk2 (5' -gcgattc . . tccattg- $3^{\prime}$, common to all Girk2 isoforms (Wei et al., 1998), and mouse Girk3 (5' caggaga . . . aacaagc- $3^{\prime}$ ). Hybridization was performed as described (Bartsch et al., 1992), and labeling was detected by alkaline phosphatasecoupled antibodies to digoxigenin. Selected sections were Nisslcounterstained for identification of brain structures (Paxinos and Franklin, 2003).

Immunoblotting. Three panels of adult WT and GIRK KO mice were killed by $\mathrm{CO}_{2}$ asphyxiation. Brains were removed and rinsed in ice-cold PBS. Hippocampi were extracted and homogenized in $2 \mathrm{ml}$ of buffer containing (in mM) 25 Tris, $\mathrm{pH} 7.5,150 \mathrm{NaCl}, 5$ EDTA, pH 8.0, and 1 DTT and a protease inhibitor mixture containing $0.35 \mu \mathrm{g} / \mathrm{ml} \mathrm{PMSF}$, $1.7 \mu \mathrm{g} / \mathrm{ml}$ aprotinin, $0.7 \mu \mathrm{g} / \mathrm{ml}$ pepstatin, and $10 \mu \mathrm{g} / \mathrm{ml}$ leupeptin. Samples were centrifuged at low speed $(2200 \times g)$, and the crude membrane fraction was pelleted by centrifugation at $200,000 \times g$ for $30 \mathrm{~min}$. Pellets were resuspended in $1 \mathrm{ml}$ of a $2 \%$ SDS solution containing $1 \mathrm{~mm}$ DTT and the protease inhibitor mixture. Samples were centrifuged for $5 \mathrm{~min}$ at $500 \times g$ to remove insoluble contents. Immunoblotting was performed as described previously (Bettahi et al., 2002; Marker et al., 2002; Torrecilla et al., 2002). Densitometry was performed using ImageQuant software (Molecular Dynamics, Sunnyvale, CA). For analysis of GIRK subunit levels in the hippocampus, the appropriate region in the lane corresponding to the $\mathrm{KO}$ sample relevant to the target antibody was taken as background (density value $=0$ ). For each of the three panels of WT and GIRK KO mice, two blots for each GIRK subunit were run, and signal intensities were averaged to obtain a single data point. All data points were normalized to the mean signal intensity calculated from the WT samples.

Immunohistochemistry and immunoelectron microscopy. Procedures for the isolation of brain tissue from adult WT and GIRK KO mice for immunohistochemistry and immunoelectron microscopy experiments before and after embedding were described previously (Marker et al., 2005). When a single primary antibody was used, it was visualized by the silver-intensified immunogold reaction. In colabeling experiments, VGluT1 immunoreactivity was visualized by the immunoperoxidase reaction, and GIRK subunit immunoreactivity was revealed with the silverintensified immunogold reaction. Data presented are representative of results obtained with three different and complete panels of wild-type and GIRK KO mouse brain tissue.

To establish the relative abundance of GIRK1 and GIRK2 immunoreactivity in dendritic spines, quantification of immunolabeling was performed in the stratum radiatum from $60 \mu \mathrm{m}$ coronal slices as described (Lujan et al., 1996). For each of two animals, three samples of tissue were obtained (six total blocks). Electron microscopic serial ultrathin sections were cut close to the surface of each block because immunoreactivity decreased with depth. Randomly selected areas were captured at a final magnification of $45,000 \times$, and measurements covered a total section area of $\sim 2000 \mu \mathrm{m}^{2}$. All spines establishing synapses with putative glutamatergic axon terminals were counted and assessed for the presence of immunoparticles. Only the heads of spines were analyzed because spine necks were rarely connected to spine heads in single sections. Because differences in the distribution of gold particles among samples were not statistically significant $(p>0.46$, Kolmogorov-Smirnov nonparametric test), the data were pooled. The length of the synaptic membrane specialization and the extrasynaptic membrane from all immunopositive spines was measured using a digitizing tablet and appropriate software (SigmaScan Pro; Jandel Scientific, Ekzath, Germany). The extrasynaptic spine membrane was divided into $60 \mathrm{~nm}$ bins. The distance between the closest edge of the postsynaptic density and the center of the immunoparticles was measured along the spine membrane. To obtain a normalized value of the relative abundance of GIRK1 and GIRK2 along the spine, the number of gold particles was expressed as relative frequency in bins corresponding to $60 \mathrm{~nm}$ membrane segments of plasma membrane.

Slice electrophysiology. Horizontal slices $(300 \mu \mathrm{M})$ from WT and GIRK $\mathrm{KO}$ mice (16-28 d) containing the substantia nigra pars compacta ( $\mathrm{SNc}$ ) and/or hippocampus were prepared in slicing solution containing the following (in mM): 110 choline-Cl, $2.5 \mathrm{KCl}, 1.25 \mathrm{NaH}_{2} \mathrm{PO}_{4}-\mathrm{H}_{2} \mathrm{O}, 25$ $\mathrm{NaHCO}_{3}, 0.5 \mathrm{CaCl}_{2}-2 \mathrm{H}_{2} \mathrm{O}, 1.1 \mathrm{MgCl}_{2}$, and 11 glucose. The slicing solution was bubbled with $95 \% \mathrm{O}_{2}$ and $5 \% \mathrm{CO}_{2}$ and maintained at $4-8^{\circ} \mathrm{C}$. Slices were stored at room temperature for $\leq 1 \mathrm{~h}$ in artificial CSF (ACSF; in mM: $119 \mathrm{NaCl}, 2.5 \mathrm{KCl}, 1 \mathrm{NaH}_{2} \mathrm{PO}_{4}, 26.5 \mathrm{NaHCO}_{3}, 1.3 \mathrm{MgSO}_{4}, 2.5$ $\mathrm{CaCl}_{2}$, and 11 glucose) bubbled with $95 \% \mathrm{O}_{2}$ and $5 \% \mathrm{CO}_{2}$. Neurons were visualized using an Olympus Optical (Tokyo, Japan) BX51WI microscope equipped with infrared optics. Holding currents, access resistance, and membrane resistance were measured with a Multiclamp 700A amplifier, Digidata 1320, and pCLAMP version 9 software (Axon Instruments, Union City, CA). Currents were low-pass filtered at $2 \mathrm{kHz}$, sampled at $4 \mathrm{kHz}$, and recorded directly onto computer hard disk.

Borosilicate patch pipettes $(3-5 \mathrm{~m} \Omega)$ were filled with a solution containing the following (in mM): $140 \mathrm{~K}$-gluconate, $2 \mathrm{MgCl}_{2}, 1.1 \mathrm{EGTA}, 5$ HEPES/KOH, 2 NaATP, $0.3 \mathrm{Na}_{3} \mathrm{GTP}$, and 5 phosphocreatine, pH 7.4. Bath (ACSF) and drug solutions were applied using a Dynamax peristaltic pump (Rainin, Woburn, MA). Experiments were performed at room temperature, and all voltage values were corrected for junction potential $(-16 \mathrm{mV})$. Series resistance and capacitance compensations were not performed because these manipulations did not significantly affect peak currents or kinetics but did increase noise and decrease recording stability, complicating the measurement of small currents in GIRK knock-out slices. After establishment of the whole-cell access, resting membrane potentials were measured. Subsequently, recording stability was assessed in voltage clamp mode $\left(V_{\text {hold }}=-62 \mathrm{mV}\right)$ over a $5-10 \mathrm{~min}$ interval. Holding current, input resistance $\left(R_{\mathrm{in}}\right)$, and access resistance $\left(R_{\mathrm{A}}\right)$ values were extracted from current responses to periodic $(0.2 \mathrm{~Hz})$ voltage steps $(-5 \mathrm{mV}, 800 \mathrm{~ms})$ and were monitored throughout the experiment. Only those experiments with stable ( $<20 \%$ variation) and low $R_{\mathrm{A}}$ values $(<25$ 
$\mathrm{M} \Omega$ ) over the entire experiment were included in the final data set. For single-dose experiments, cells were given $50 \mu \mathrm{M}$ baclofen for 5-10 min before application of $1 \mu \mathrm{M}$ CGP54626. For multidose studies, cells were challenged with $0.5 \mathrm{and} /$ or $5 \mu \mathrm{M}$ baclofen and then $50 \mu \mathrm{M}$ baclofen. For $\mathrm{Ba}^{2+}$ experiments, cells were perfused with ACSF supplemented with $1 \mathrm{~mm}$ $\mathrm{Ba}^{2+}$ for 5 min before baclofen application. Dopamine neurons in the SNc were identified by the presence of (1) a hyperpolarizationactivated current $\left(I_{\mathrm{h}}\right),(2)$ low-frequency $(\leq 2$ $\mathrm{Hz}$ ) action potentials induced by injection of $+100 \mathrm{pA}$ holding current, and (3) a sag-shaped membrane potential response to current injections of -200 and $-300 \mathrm{pA}$, as described (Grace and Onn, 1989; Lacey et al., 1989).

Lipid raft isolation. For each preparation, two brains taken from adult WT mice were processed through two rounds of homogenization in TNE buffer consisting of (in mM) 25 Tris$\mathrm{HCl}, 150 \mathrm{NaCl}$, and 5 EDTA, pH 7.5, and a protease inhibitor mixture containing (in $\mu \mathrm{g} /$ ml) 40 aprotinin, 40 leupeptin, 20 pepstatin A, and 40 PMSF. Samples were centrifuged at $1000 \times g$ for $10 \mathrm{~min}$ at $4^{\circ} \mathrm{C}$; membranes were pelleted by centrifugation at $100,000 \times g$ for $1 \mathrm{~h}$ at $4^{\circ} \mathrm{C}$; and the resultant pellet was suspended in $0.5 \mathrm{ml}$ of TNE buffer, $\mathrm{pH} 11$, containing $1 \%$ Triton X-100. Samples were adjusted to $40 \%$ sucrose, transferred to an ultracentrifuge tube, gently covered with $1.5 \mathrm{ml}$ of $36 \%$ sucrose and 2 $\mathrm{ml}$ of $10 \%$ sucrose solutions prepared in TNE buffer, $\mathrm{pH} 11$, and centrifuged at 100,000 $\times g$ for $16 \mathrm{~h}$ at $4^{\circ} \mathrm{C}$. Subsequently, $6 \times 700 \mu \mathrm{l}$ fractions were removed, diluted with $3 \mathrm{ml}$ of TNE buffer, $\mathrm{pH} 11$, and centrifuged at 100,000 $\times g$ for $1.5 \mathrm{~h}$ at $4^{\circ} \mathrm{C}$. Pellets were suspended in $50 \mu \mathrm{l}$ of $2 \%$ SDS loading buffer before immunoblotting. Fractions 1-3 did not contain appreciable protein and were not reactive for any of the antibodies tested. Three separate lipid raft isolations were performed. For each preparation, total target signal intensity in fractions $4-6$ was calculated by densitometry, and the percentage of total signal intensity in each fraction was calculated.

Statistical analysis. Data are presented as the mean \pm SEM. Statistical comparisons were made using one-way ANOVA, followed by Tukey's honestly significant difference post hoc test for pair-wise comparisons. The level of significance was considered $p<0.05$.

\section{Results}

We examined the distribution of GIRK subunit mRNAs throughout the adult mouse CNS, reasoning that a comparative analysis of GIRK channel function and distribution in neurons with different subunit repertoires would highlight the functional relevance of individual subunits. GIRK1, GIRK2, and GIRK3 mRNA levels and distributions were evaluated by in situ hybridization in brain sections taken from adult WT mice. Sections from GIRK $\mathrm{KO}$ mice were processed in parallel to assess the specificity of any observed signals. Our observations were mostly consistent with previous comprehensive reports in the rodent brain (Kobayashi et al., 1995; Karschin et al., 1996; Chen et al., 1997), suggesting a high degree of overlap between neuronal GIRK subunits.

In the hippocampus, GIRK1, GIRK2, and GIRK3 mRNAs
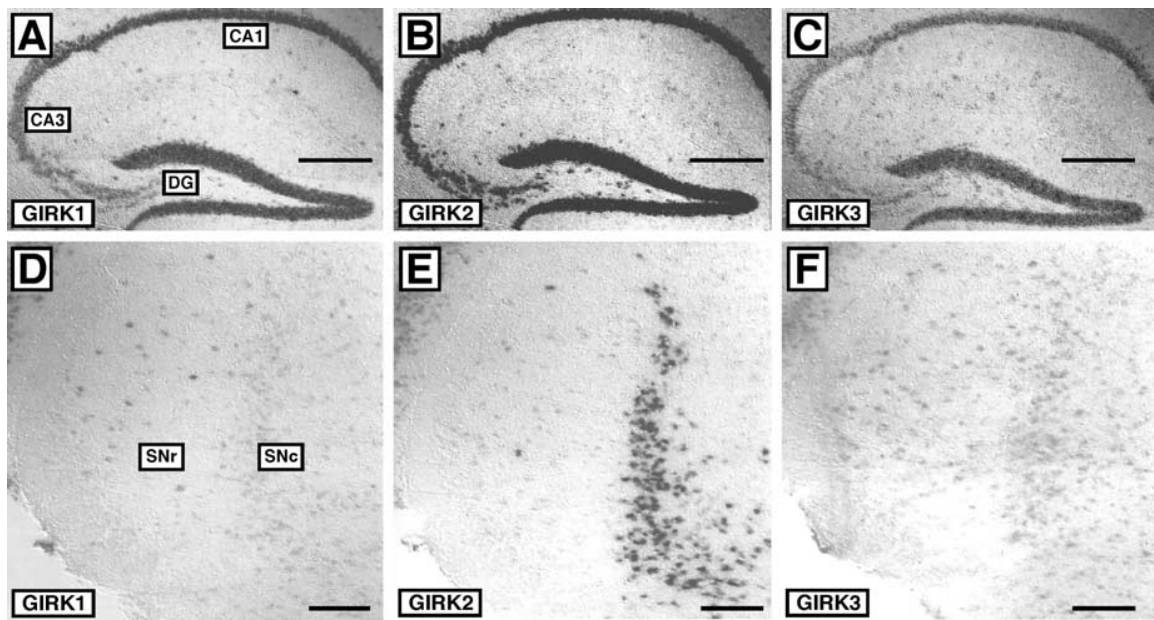

Figure 1. GIRK subunit mRNA distribution in the hippocampus and substantia nigra. GIRK mRNA distributions were evaluated by in situ hybridization in sections from WT and GIRK K0 mice. In sections from WT mice, mRNAs for GIRK1 (A), GIRK2 (B), and GIRK3 clearly evident in CA1 and CA3 pyramidal neurons, as well as granule cells of the dentate gyrus (DG). There was no specific staining for GIRK mRNAs in sections from the appropriate GIRK KO mouse (data not shown). Images are representative of data examined in the SN. Scale bars: $\boldsymbol{A}-\boldsymbol{C}, 500 \mu \mathrm{m} ; \boldsymbol{D}-\boldsymbol{F}, 100 \mu \mathrm{m}$.
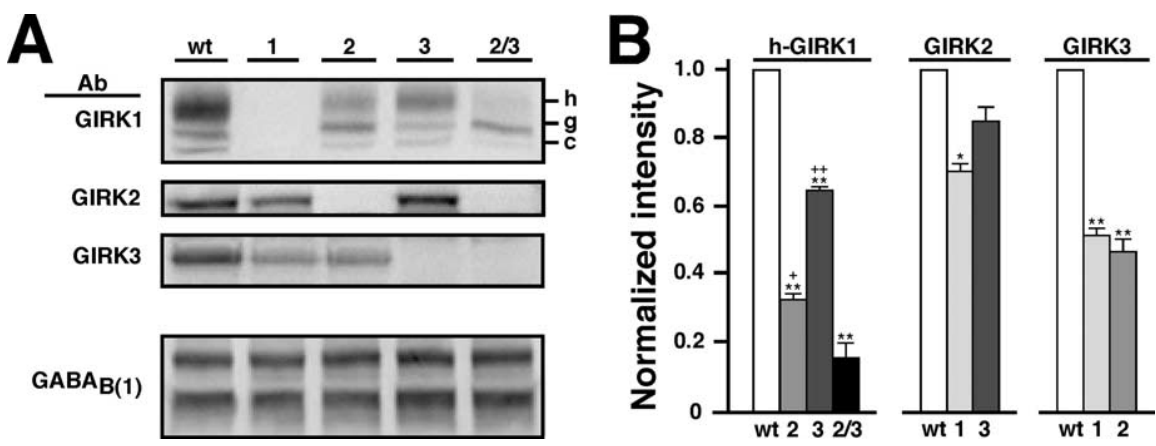

Figure 2. GIRK subunit proteins are found in the mouse hippocampus. A, Representative immunoblots of hippocampal membrane protein samples from WT, GIRK1 K0 (1), GIRK2 (2), GIRK3 (3), and GIRK2/GIRK3 (2/3) K0 mice. Blots were probed with ntibodies (Ab) for GIRK1, GIRK2, GIRK3, and GABA $\mathrm{B}_{\mathrm{B}(1 / \mathrm{a}) \mathrm{b})}$. $\mathrm{GABA}_{B}$ immunoreactivity was observed as two prominent bands a 100 kDA (Malitschek et al., 1998; Fritschy et al., 1999). As described previously (Kennedy et al., 1996, 1999; Marker et l., 2002; Torrecilla et al., 2002), GIRK1 immunoreactivity was visualized as three bands, the lower molecular weight versions 列

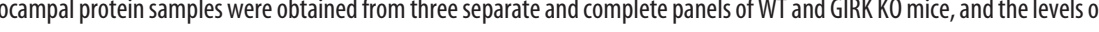
GIRK1 (heavily glycosylated form, h-GIRK1), GIRK2, GIRK3, and GABA ${ }_{B(1)}$ (both isoforms) were determined. There was no effect of GIRK subunit ablation $\mathrm{GABA}_{\mathrm{B}(1)}$ receptor levels $\left(F_{(4,10)}=1.764 ; p=0.213\right.$ ) (data not shown). ${ }^{*} p<0.05$; ${ }^{* *} p<0.01$ versus WT; ${ }^{+} p<0.05 ;{ }^{++} p<0.01$ versus GIRK2/GIRK3 K0. 

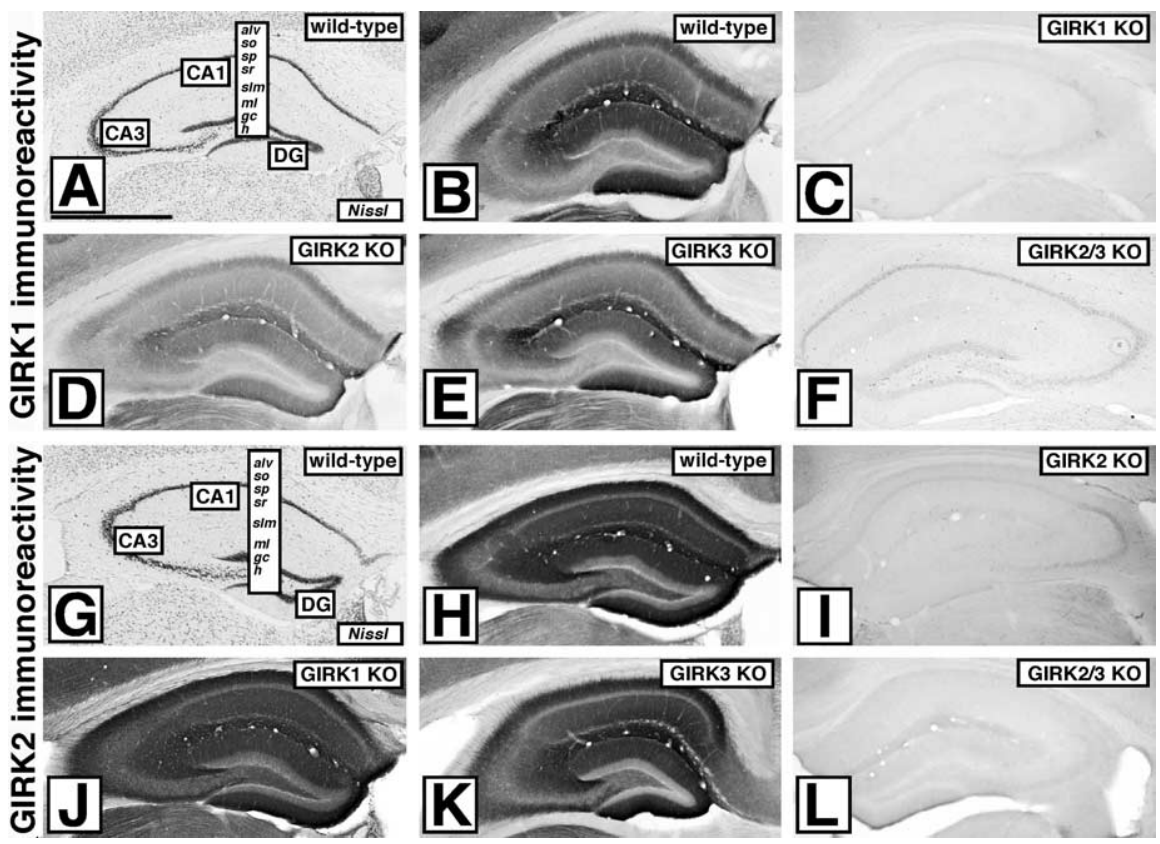

Figure 3. Distribution of GIRK1 and GIRK2 subunits in the hippocampus. Immunohistochemical detection of GIRK1 $(\boldsymbol{A}-\boldsymbol{F})$ and GIRK2 (G- $\boldsymbol{L}$ ) in the hippocampal formations of WT, GIRK1, GIRK2, GIRK3, and GIRK2/GIRK3 (GIRK2/3) K0 mice is shown. Staining patterns are representative of data obtained from three different and complete panels of adult WT and GIRK KO mice. $A, G$, Niss staining of GIRK1 and GIRK2 in WT hippocampi, respectively. alv, Alveus; so, stratum oriens; sp, stratum pyramidale; sr, stratum radiatum; slm, stratum lacunosum-moleculare; $\mathrm{ml}$, molecular layer; gc, granule cell; h, hilus; DG, dentate gyrus. B, C, GIRK1 immunolabeling in a WT $(\boldsymbol{B})$ and GIRK1 KO ( $\boldsymbol{C}$ hippocampus. $\boldsymbol{D}-\boldsymbol{F}$, Residual GIRK1 immunoreactivity in sections from GIRK KO mice. $\boldsymbol{H}$, GIRK2 immunolabeling in a WT hippocampus. I, $\boldsymbol{L}$, GIRK2 labeling in GIRK2 KO (I) and GIRK2/GIRK3 KO (L) mice. J, $\boldsymbol{K}$, № significant changes in immunoreactivity for GIRK2 were detected in the hippocampal formations of GIRK1 KO $(J)$ and GIRK3 KO $(K)$ mice. Scale bar, $1 \mathrm{~mm}$.

ily restricted to the $\mathrm{SNc}$. Based on these observations, we proceeded to examine the subunit composition and subcellular distributions of GIRK channels in the hippocampus and SNc, structures evincing distinct GIRK subunit expression patterns.

The three neuronal GIRK subunits were clearly present in WT hippocampal membrane protein extracts, and the levels of each subunit varied as a function of genotype (Fig. 2). The absence of GIRK1 was correlated with lower levels of GIRK2 $(30 \pm 3 \%$ reduction; $p<0.05)$ and GIRK3 $(49 \pm 2 \%$ reduction; $p<0.01)$ (Fig. $2 B$ ). The level of residual heavily glycosylated $(\sim 70 \mathrm{kDA})$ GIRK1 was significantly lower in the absence of either GIRK2 $(69 \pm 1 \%$ reduction; $p<0.01)$ or GIRK3 $(36 \pm 1 \% ; p<0.01)$. In samples from GIRK2/GIRK3 KO mice, the level of heavily glycosylated GIRK1 was even lower $(83 \pm 2 \%$ reduction; $p<0.01)$. Because mature glycosylation of GIRK1 occurs as a consequence of channel heteroassembly and is correlated with plasma membrane distribution (Krapivinsky et al., 1995a; Kennedy et al., 1999), the impact of GIRK2 and/or GIRK3 ablation on the abundance of this GIRK1 species likely reflects the loss of functional GIRK1-containing heteromultimers. Thus, these data support the contention that GIRK1 forms functional channels primarily with GIRK2 and, to a lesser extent, GIRK3 in the hippocampus.

We next examined the regional distribution of GIRK subunits in the hippocampus using immunohistochemistry. Although available GIRK3 antisera displayed nonspecific labeling as assessed in sections from GIRK3 KO mice (data not shown), GIRK1 and GIRK2 antibodies were quite specific (Fig. 3). Staining for GIRK1 and GIRK2 in the WT hippocampus was strongest in the molecular layer of the dendate gyrus and stratum lacunosummoleculare and in the distal half of the stratum radiatum of the CA1 and CA3 areas (Fig. 3B, H). The alveus, stratum oriens, and proximal half of the stratum radiatum of the CA1 and CA3 areas were labeled less intensely, and minimal immunoreactivity was found in the stratum pyramidale, stratum lucidum, and dentate hilus for both subunits. GIRK1 was preferentially located in distal dendrites, whereas GIRK2 was more uniformly distributed among distal, proximal, and basal dendrites (compare staining for both subunits in the stratum lacunosum-moleculare and the distal half of the stratum radiatum). GIRK2 immunostaining was relatively unaffected by the loss of either GIRK1 (Fig. 3J) or GIRK3 (Fig. $3 \mathrm{~K})$. The former observation contrasts with immunoblotting results (Fig. 2), which showed a significant $30 \%$ reduction in GIRK2 protein levels in membrane protein extracts from GIRK1 knock-out hippocampi. This discrepancy is perhaps explained by the fact that the immunohistochemical approach cannot readily discriminate between plasma membrane and intracellular labeling. Consistent with immunoblotting data, GIRK1 immunostaining was found to be less intense in sections from GIRK2 KO mice (Fig. 3D), modestly reduced in sections from GIRK3 KO mice (Fig. 3E), and dramatically reduced and primarily confined to cell bodies in sections from GIRK2/GIRK3 KO mice (Fig. $3 F)$. Thus, this approach provided further evidence that GIRK1 interacts with both GIRK2 and GIRK3 in the CA1 region of the mouse hippocampus.

We next compared resting electrophysiological properties and neurotransmitter-evoked currents in hippocampal neurons in slices taken from WT and GIRK KO mice. We decided to focus on CA1 pyramidal neurons because these neurons were shown previously to exhibit robust neurotransmitter-induced GIRK currents (Luscher et al., 1997). Compared with CA1 neurons from WT mice, the resting membrane potentials of CA1 neurons from GIRK KO mice were all relatively depolarized (Table 1). Significant depolarization was observed in CA1 neurons from GIRK2 $\mathrm{KO}$ and GIRK2/GIRK3 KO mice, consistent with previous reports (Luscher et al., 1997; Chen and Johnston, 2005).

The $\mathrm{GABA}_{\mathrm{B}}$ receptor agonist baclofen $(0.5-250 \mu \mathrm{M})$ evoked outward current in CA1 neurons from WT mice (Fig. 4). The outward current was accompanied by a marked decrease in input resistance, showed little or no desensitization during a 10 min agonist exposure, and was reversed with the $\mathrm{GABA}_{\mathrm{B}}$ receptor antagonist CGP54626 (1 $\mu \mathrm{M})$. The current response was dose dependent, with a maximum response observed at $50 \mu \mathrm{M}$ baclofen $(92 \pm 12 \mathrm{pA} ; n=18)$ (Fig. $4 A$ ) and an approximate $\mathrm{EC}_{50}$ value of $5 \mu \mathrm{M}$ (Fig. $4 D$ ). In the presence of the nonselective $\mathrm{K}^{+}$ channel blocker $\mathrm{Ba}^{2+}(1 \mathrm{mM})$, the current was markedly attenuated ( $16 \pm 2 \mathrm{pA} ; n=7$ ) (Fig. $4 C$, gray bar), indicating that the postsynaptic inhibitory effect of $\mathrm{GABA}_{\mathrm{B}}$ receptor activation on CA1 neurons is mediated primarily by $\mathrm{K}^{+}$channels. Indeed, baclofen-evoked currents in CA1 neurons from GIRK1 KO (24 \pm $2 \mathrm{pA} ; n=9)$ and GIRK2 KO $(24 \pm 2 \mathrm{pA} ; n=11)$ mice were significantly smaller than currents in WT neurons $(p<0.05)$, suggesting that these two subunits form the channel responsible for most of the baclofen-evoked current. 
Table 1. Group data for electrophysiology studies

\begin{tabular}{|c|c|c|c|c|c|c|c|c|c|}
\hline \multirow[b]{3}{*}{ Genotype } & \multicolumn{5}{|c|}{ Hippocampus } & \multicolumn{4}{|c|}{ SNc } \\
\hline & \multicolumn{2}{|c|}{ Mice } & \multicolumn{3}{|c|}{ CA1 neurons } & \multicolumn{2}{|c|}{ Mice } & \multicolumn{2}{|c|}{ Dopamine neurons } \\
\hline & $n$ & Age (d) & $n$ & $\mathrm{MP}(\mathrm{mV})$ & $R_{\text {in }}(\mathrm{M} \Omega)$ & $n$ & Age (d) & $n$ & $R_{\text {in }}(\mathrm{M} \Omega)$ \\
\hline WT & 16 & $23 \pm 1$ & 34 & $-75 \pm 1$ & $402 \pm 47$ & 8 & $21 \pm 2$ & 22 & $712 \pm 70$ \\
\hline GIRK1 KO & 6 & $21 \pm 1$ & 13 & $-72 \pm 1$ & $424 \pm 32$ & 5 & $19 \pm 1$ & 8 & $546 \pm 104$ \\
\hline GIRK2 KO & 7 & $20 \pm 1$ & 20 & $-71 \pm 1^{*}$ & $446 \pm 32$ & 4 & $19 \pm 2$ & 11 & $957 \pm 285$ \\
\hline GIRK3 KO & 6 & $19 \pm 1$ & 15 & $-73 \pm 1$ & $412 \pm 50$ & 4 & $18 \pm 1$ & 7 & $727 \pm 86$ \\
\hline GIRK2/3 KO & 2 & 19 & 11 & $-67 \pm 2^{* * * *}$ & $581 \pm 44$ & & & & \\
\hline$F$ & & & & $F_{(88,92)}=8.1$ & $F_{(88,92)}=1.6$ & & & & $F_{(44,47)}=1.0$ \\
\hline
\end{tabular}

Numbers and ages of mice from each genotype used for the analysis of baclofen-evoked currents in the hippocampus and SN are shown. Resting membrane potentials (MP) and $R_{\text {in }}$ were measured for each CA1 neuron and compared across genotypes. Significantly depolarized MPs were observed in GIRK2 and GIRK2/GIRK3 K0 mice. Because of the spontaneous firing observed in SNc DA neurons, MPs were not determined. ${ }^{*} p<0.05$ versus WT; ** $p<0.05$ versus GIRK3 K0.

Although the residual baclofen-induced current seen in CA1 neurons from GIRK1 $\mathrm{KO}$ and GIRK2 $\mathrm{KO}$ mice was small, it was still larger than the $\mathrm{Ba}^{2+}$-insensitive current in WT CA1 neurons. Furthermore, $\mathrm{Ba}^{2+}$ significantly reduced the baclofen-induced current in CA1 neurons from GIRK2 $\mathrm{KO}$ mice (Fig. 4C, gray bar). Accordingly, we measured the baclofen response in CA1 neurons from GIRK3 $\mathrm{KO}$ and GIRK2/GIRK3 $\mathrm{KO}$ mice. The potency of baclofen in CA1 neurons from GIRK3 $\mathrm{KO}$ mice was indistin-

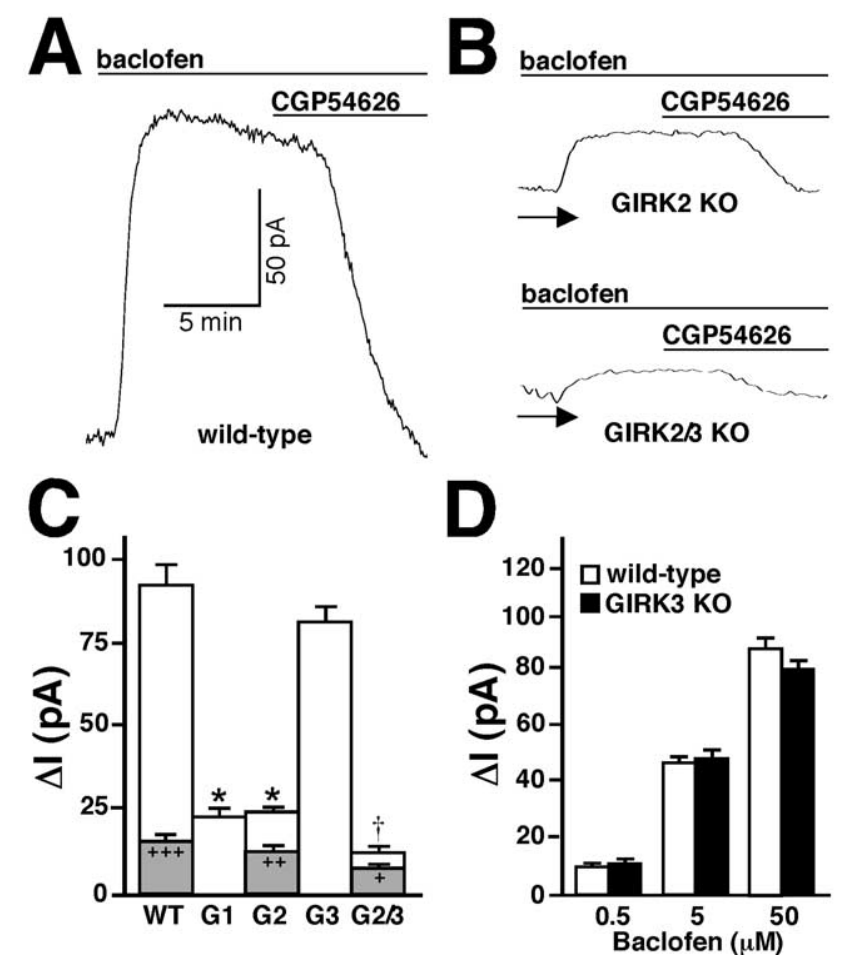

Figure 4. Baclofen-induced current in CA1 neurons from WT and GIRK KO mice. Currents evoked by baclofen were measured in hippocampal slices from WT and GIRK KO mice. Holding potential was $-62 \mathrm{mV}$. $A$, Typical current evoked by baclofen $(50 \mu \mathrm{M})$ in a CA1 neuron from a WT mouse. The outward current was reversed with the $\mathrm{GABA}_{\mathrm{B}}$ receptor antagonist CGP54626 $(1 \mu \mathrm{m})$. The holding current before baclofen application in this experiment was $90 \mathrm{pA}$. $\boldsymbol{B}$, Typical baclofen-evoked currents in CA1 neurons from GIRK2 and GIRK2/GIRK3 (GIRK2/3) K0 mice. The arrow identifies the zero current levels. C, Average peak current evoked by $50 \mu \mathrm{m}$ baclofen in CA1 neurons from WT ( $n=18), \operatorname{GIRK1}(\mathrm{G} 1 ; n=9), \operatorname{GIRK2}(\mathrm{G} 2 ; n=11), \mathrm{GIRK} 3(\mathrm{G} 3 ; n=7)$, and GIRK2/GIRK3 (G2/3; $n=7)$ KO mice. For some WT $(n=7)$, GIRK2 KO $(n=8)$, and GIRK2/GIRK3 double-knock-out $(n=4)$ recordings, baclofen-evoked currents were measured in the presence of $1 \mathrm{~mm} \mathrm{Ba}^{2+}$ (peak currents are shown in gray). ${ }^{*} p<0.05$ versus WT; ${ }^{\dagger} p<0.01$ versus GIRK1 and GIRK2 K0; ${ }^{+} p<0.05 ;{ }^{++} p<0.01 ;{ }^{++}+{ }^{+}<0.001$ versus control (within genotype). $\boldsymbol{D}$, Average peak currents evoked by $0.5,5$, and $50 \mu \mathrm{m}$ baclofen in (A1 neurons from WT $(n=8)$ and GIRK3 K0 $(n=7)$ mice. guishable from that in WT mice (Fig. $4 D$ ), as was maximal current $(82 \pm 8 \mathrm{pA} ; n=8)$ (Fig. $4 C$ ). In CA1 neurons from GIRK2/ GIRK3 KO mice, however, baclofen-induced current (12 $\pm 2 \mathrm{pA}$; $n=7$ ) (Fig. $4 B, C$ ) was significantly smaller than the responses measured in GIRK1 $\mathrm{KO}$ and GIRK2 $\mathrm{KO}$ mice. Interestingly, baclofen-evoked currents in GIRK2/GIRK3 KO CA1 neurons measured in the presence of $1 \mathrm{~mm} \mathrm{Ba}^{2+}(7 \pm 1 \mathrm{pA} ; n=4)$ were slightly though significantly $(p<0.05)$ smaller than currents measured in the absence of $\mathrm{Ba}^{2+}$, perhaps indicating the presence of a residual $\mathrm{K}^{+}$channel modulated by $\mathrm{GABA}_{\mathrm{B}}$ receptor stimulation. Altogether these data argue, however, that the simultaneous ablation of GIRK 2 and GIRK 3 results in a $\geq 90 \%$ reduction in the $\mathrm{Ba}^{2+}$-sensitive component of the baclofen-evoked outward current in CA1 pyramidal neurons.

We used electron microscopy to study the subcellular distributions of GIRK1 and GIRK2 in the stratum radiatum, a region consisting primarily of proximal dendrites from CA1 neurons and exhibiting prominent staining for GIRK1 and GIRK2 (Fig. 5). Labeling for GIRK1 (Fig. 5A-E) and GIRK2 (Fig. 5F-K) in WT sections was found primarily along the plasma membrane but also associated with the endoplasmic reticulum (ER) cisterna of dendritic shafts and spine apparatus (36 and 32\% of all particles examined for GIRK1 and GIRK2, respectively) (Fig. 5B,J). Of the immunoparticles found in the plasma membrane, most $(85 \%$ of GIRK $1 ; n=1568$; and $87 \%$ of GIRK $2 ; n=1308$ ) were found in the postsynaptic compartment of interneurons (data not shown) and pyramidal cells. GIRK1 and GIRK2 were observed primarily at extrasynaptic and perisynaptic positions in dendritic spines in contact with axon terminals, likely deriving from Schaffer collaterals. Analysis of the position of gold particles (GIRK1, $n=331$; GIRK2, $n=324$ ) in relation to the closest edge of the postsynaptic membrane specialization revealed that GIRK1 and GIRK2 share virtually the same subcellular distribution in dendritic spines in CA1 neurons (Fig. $5 L$ ). A potentially significant difference in the subsynaptic distributions of postsynaptic GIRK1 and GIRK2 was revealed, however, with a postembedding immunogold technique. GIRK1 immunoparticles were never found, whereas GIRK2 labeling was often seen within the postsynaptic specialization (Fig. 5C,I).

Given that electrophysiological studies in the hippocampus have suggested that GIRK channels do not contribute to presynaptic inhibition, we were surprised to find that the remaining plasma membrane labeling for GIRK1 (15\%) and GIRK2 (13\%) was found in presynaptic terminals establishing asymmetrical (putative excitatory) synapses on spines (Fig. 5D,J). Doublelabeling approaches indicated that the presynaptic GIRK subunits (Fig. $5 E, K$ ) were found in terminals immunoreactive for the synaptic vesicle glutamate transporter VGluT1, a marker of glu- 

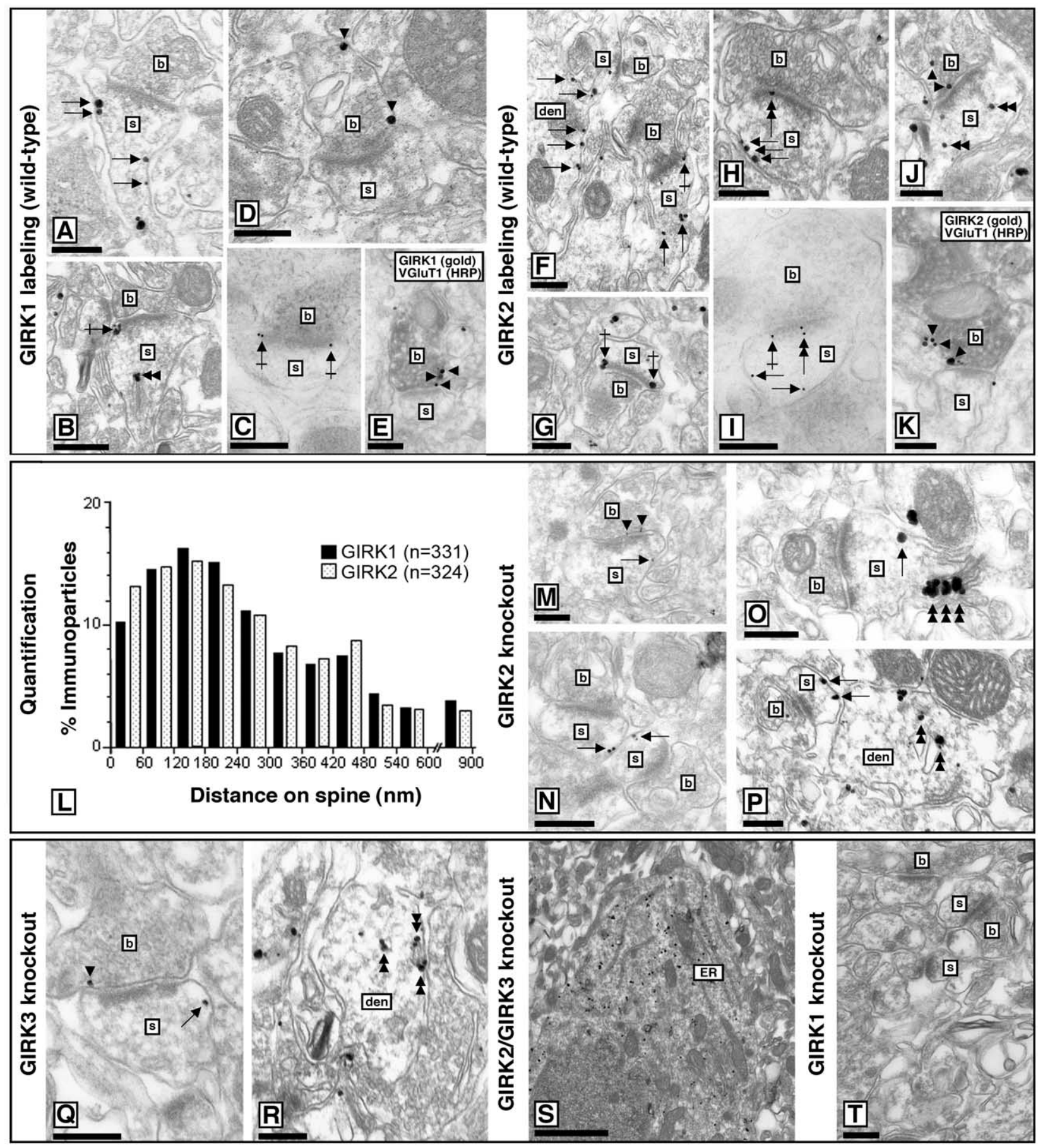

Figure 5. Subcellular distributions of GIRK subunits in the hippocampus. Electron micrographs show immunolabeling for GIRK1 and GIRK2 in the stratum radiatum of the CA1 area of WT and GIRK K0 mice. den, Dendritic shaft; $b$, bouton; $s$, dendritic spine. $A, B$, GIRK1 immunoparticles were observed primarily along the extrasynaptic plasma membrane (arrows) of dendritic spines of CA1 neurons from WT mice, although perisynaptic labeling (crossed arrow) was also frequently observed. GIRK1 labeling was also found associated with ER cisterna of dendritic shafts and with the spine apparatus (double arrowheads) of spines. C, GIRK1 labeling was never detected within the postsynaptic specialization, as demonstrated with postembedding techniques. D, E, GIRK1 immunoparticles at presynaptic sites were localized to the extrasynaptic plasma membrane (arrowheads) and occasionally to the presynaptic membrane specialization of axon terminals establishing putative excitatory synapses on spines, as confirmed in double-labeling experiments with VGluT1. $\boldsymbol{F}-\boldsymbol{H}, \mathrm{GIRK2}$ immunoparticles were found along the extrasynaptic plasma membrane (arrows) of dendritic shafts of CA1 cells from WT mice, mainly associated with dendritic spines. Both perisynaptic ( $\boldsymbol{G}$, crossed arrows) and synaptic $(\boldsymbol{H}$, double arrow) labeling at asymmetrical synapses was detected, the latter confirmed using postembedding techniques (I).J, $K$, , IRK2 immunoparticles were detected at presynaptic sites (arrowheads), mainly in the extrasynaptic plasma membrane, and occasionally in the presynaptic membrane specialization of axon terminals establishing putative excitatory synapses on spines, as confirmed using double-labeling experiments with VGluT1. Note also the GIRK2 immunoreactivity associated with ER cisterna of dendritic shafts and the spine apparatus of dendritic spines (J, double arrowheads). L, Distribution of GIRK1 and GIRK2 on dendritic spines of CA1 neurons. Data are displayed as percentage frequency of particles in 60 -nm-wide bins, starting at the edge of the postsynaptic specialization. $M-T$, Electron micrographs showing GIRK1 immunoreactivity in the stratum radiatum of the CA1 area in sections taken from GIRK2 KO $(\boldsymbol{M}-\boldsymbol{P})$, GIRK3 KO $(\boldsymbol{Q}, \boldsymbol{R})$, GIRK2/GIRK3 KO (S), and GIRK1 K0 (T) mice. Note that GIRK1 immunoreactivity was still observed along the extrasynaptic plasma membrane (arrows) of dendritic spines and shafts of CA1 neurons from GIRK2 K0 and GIRK3 K0 mice. Immunoparticles for GIRK1 were also observed at perisynaptic (data not shown) positions and at presynaptic sites along the extrasynaptic plasma membrane (arrowheads) of axon terminals establishing putative excitatory synapses on dendritic spines. A higher proportion of immunoparticles for GIRK1 was detected in the ER cisterna of dendritic shafts and the spine apparatus (double arrowhead). Immunoreactivity for GIRK1 was primarily restricted to the ER of CA1 cells in the hippocampus of GIRK2/GIRK3 K0 mice and was absent in sections from a GIRK1 K0 mouse. Scale bars, $0.2 \mu \mathrm{m}$. 
tamatergic neurons (Li et al., 2003; Todd et al., 2003; Alvarez et al., 2004; Barr and Van Bockstaele, 2005).

The subcellular distribution and expression level of GIRK2 seen in sections from GIRK1 KO and GIRK3 KO mice were indistinguishable from those seen in WT sections (data not shown). GIRK1-labeled dendritic spines (and immunoparticles per spine), however, were observed less frequently in both GIRK2 KO (Fig. 5M-P) and GIRK3 KO (Fig. 5Q,R) mice. In sections from these mice, GIRK1 labeling was still observed along the extrasynaptic plasma membrane of dendritic spines and shafts of pyramidal cells and interneurons. Furthermore, GIRK1 labeling was still observed at perisynaptic positions (data not shown) and at presynaptic sites along the extrasynaptic plasma membrane and presynaptic active zone of axon terminals. GIRK1 immunoparticles were more frequently associated, however, with the ER and spine apparatus (57 and 42\% of GIRK1 immunoparticles in GIRK2 KO and GIRK3 KO mice, respectively). In sections from GIRK2/ GIRK3 KO mice, GIRK1 labeling was primarily restricted to the soma (98\% of particles) (Fig. 5S). Altogether, our ultrastructural analysis of GIRK subunit distribution in WT and GIRK KO mice supports the contention that GIRK1 interacts with both GIRK2 and GIRK3 to form functional channels in CA1 pyramidal neurons and that subunit composition can vary among subcellular compartments.

The modest impact of GIRK3 ablation on baclofen-evoked current in the hippocampus contrasted with direct evidence supporting the expression of GIRK3 in CA1 neurons and indirect evidence supporting its interaction with GIRK1 in the dendritic compartment of CA1 neurons. These divergent observations led us to speculate that one or more factors contribute to the compartmentalization of $\mathrm{GABA}_{\mathrm{B}} / \mathrm{GIRK}$ signaling to emphasize the link between a subset of GIRK channels and $\mathrm{GABA}_{\mathrm{B}}$ receptors. Given that GIRK1 was identified in lipid rafts isolated from rat brain (Delling et al., 2002), we tested the hypothesis that GIRK1 and GIRK2 (but not GIRK3) coexisted with $\mathrm{GABA}_{\mathrm{B}}$ receptors in lipid rafts.

Detergent-resistant membranes from mouse brain were processed by sucrose gradient centrifugation. Six fractions representing distinct sample densities were concentrated and probed by immunoblotting for GIRK subunits, $\mathrm{GABA}_{\mathrm{B}(1)}$, and the lipid raft marker protein Fyn (Fig. 6). Consistent with previous observations, Fyn was found primarily $(77 \pm 1 \%)$ in fraction 4 (Delling et al., 2002). Signals for GIRK1 (61 $\pm 9 \%)$, GIRK2 (50 $\pm 5 \%)$, and $\mathrm{GABA}_{\mathrm{B}(1)}(68 \pm 5 \%)$ were also most prominent in this fraction. Signal for GIRK3, however, was most prominent in fraction 6 (55 $\pm 4 \%)$, a higher-density fraction exhibiting relatively little GIRK2 or $\mathrm{GABA}_{\mathrm{B}(1)}$. GIRK1 and GIRK2 signal intensities in fraction 6 were of moderate intensity $(\sim 30 \%)$, perhaps a reflection of two broad populations of GIRK channels in the CNS (raftassociated and -independent). These data provide an explanation for the modest contribution of GIRK3-containing channels to baclofen-evoked current in CA1 neurons and support the contention that an active process of compartmentalization affects the coupling of GIRK channels to receptors in a subunit-dependent manner.

Cell biological, biochemical, and electrophysiological evidence indicated that GIRK1/GIRK2 heteromultimers represent the dominant GIRK channel linked to postsynaptic $\mathrm{GABA}_{\mathrm{B}}$ receptors, whereas GIRK3-containing channels make a modest contribution to current density, in hippocampal CA1 neurons. To determine whether this subunit composition is required for effective coupling of GIRK channels to $\mathrm{GABA}_{\mathrm{B}}$ receptors in vivo, we probed the GIRK channel subunit content in the SNc. Con-
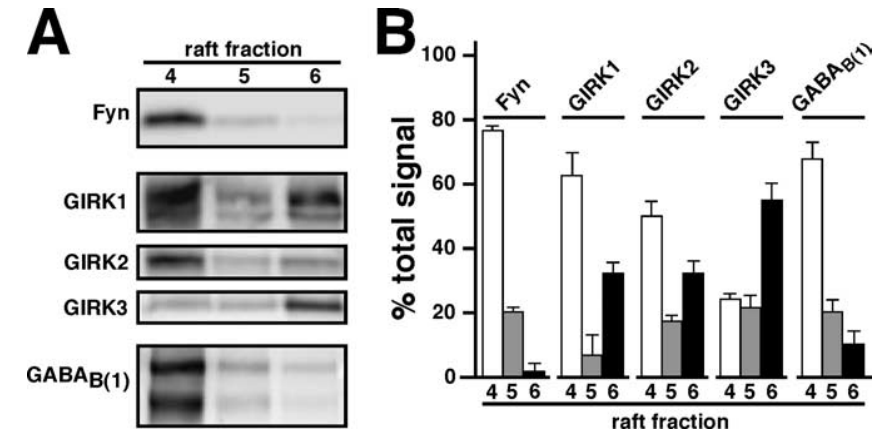

Figure 6. Compartmentalization of $\mathrm{GABA}_{\mathrm{B}} / \mathrm{GIRK}$ signaling. $\boldsymbol{A}$, Representative immunoblots showing the distribution of GIRK subunits and $G A B A_{B(1)}$ in lipid rafts isolated from WT mice. The lipid raft marker and tyrosine kinase Fyn were consistently observed in fraction 4 after sucrose gradient centrifugation of Triton X-100-insoluble membranes (Delling et al., 2002). B, Densitometric analysis of target distribution in fractions from lipid raft preparations. Three isolations of lipid rafts were performed, and qualitatively similar observations were obtained each time. The histogram shows intensity observed in each lane represented as a percentage of total signal in lanes 4-6 (percentage of total signal).

sistent with our in situ hybridization data, we were unable to detect specific GIRK1 labeling in the SNc (data not shown). GIRK2 staining, however, was prominent and most evident in dendritic arbors located in the substantia nigra pars reticulata (SNr) (Fig. 7A). Staining for GIRK2 was normal in sections from GIRK1 KO and GIRK3 KO mice (data not shown) but completely absent in sections from GIRK2 KO mice (Fig. 7B).

Ultrastructural colabeling experiments indicated that GIRK2 was found in both $\mathrm{TH}$-positive (putative dopaminergic) and THnegative (putative GABAergic) neurons in the $\mathrm{SNc}$ (Fig. 7C,D). In both neuron types, GIRK2 labeling was found primarily at extrasynaptic sites in dendrites. Furthermore, colabeling studies indicated a significant overlap in the subcellular distributions of $\mathrm{GABA}_{\mathrm{B}(1)}$ and GIRK2 in the SNc (Fig. 7E,F). Consistent with our observations in the hippocampus, a small percentage of total GIRK2 labeling was seen in presynaptic terminals establishing excitatory (asymmetrical) synapses with GIRK2-positive dendritic shafts (data not shown).

Baclofen-evoked currents were measured in SNc dopamine (DA) neurons in slices from WT and GIRK KO mice. DA neurons were identified on the basis of size and functional properties as described (Materials and Methods). Baclofen (50 $\mu \mathrm{M})$ evoked a desensitizing outward current in WT SNc neurons $(150 \pm 17 \mathrm{pA}$; $n=12$ ) (Fig. $8 \mathrm{~A}$ ). The current desensitization profile was similar to that observed in the VTA (Cruz et al., 2004) and in mammalian cells transfected with $\mathrm{GABA}_{\mathrm{B}}$ receptor subunits and GIRK2 (Mutneja et al., 2005). The baclofen-induced current was reversed by CGP54626 $(1 \mu \mathrm{M})$ and was significantly smaller in the presence of $1 \mathrm{mM} \mathrm{Ba}^{2+}(13 \pm 2 \mathrm{pA} ; n=5 ; p<0.001)$ (Fig. $\left.8 B, C\right)$. In GIRK1 KO (137 $\pm 20 \mathrm{pA} ; n=6)$ and GIRK3 KO (131 $\pm 19 \mathrm{pA}$; $n=7$ ) mice, baclofen-induced currents in SNc DA neurons were of similar magnitude and exhibited the same desensitization profile (Fig. 8C). In stark contrast, the current measured in GIRK2 KO SNc DA neurons was virtually absent $(11 \pm 2 \mathrm{pA} ; n=4$; $p<$ $0.001)$ and was completely insensitive to $1 \mathrm{~mm} \mathrm{Ba}^{2+}(10 \pm 2 \mathrm{pA}$; $n=7$ ) (data not shown). These studies suggest that the GIRK channel coupled to the $\mathrm{GABA}_{\mathrm{B}}$ receptor in SNc DA neurons is formed solely by a product(s) of the Girk2 gene.

\section{Discussion}

In this work, we probed the relevance of individual GIRK subunits to neuronal GIRK channels. We exploited the differential 


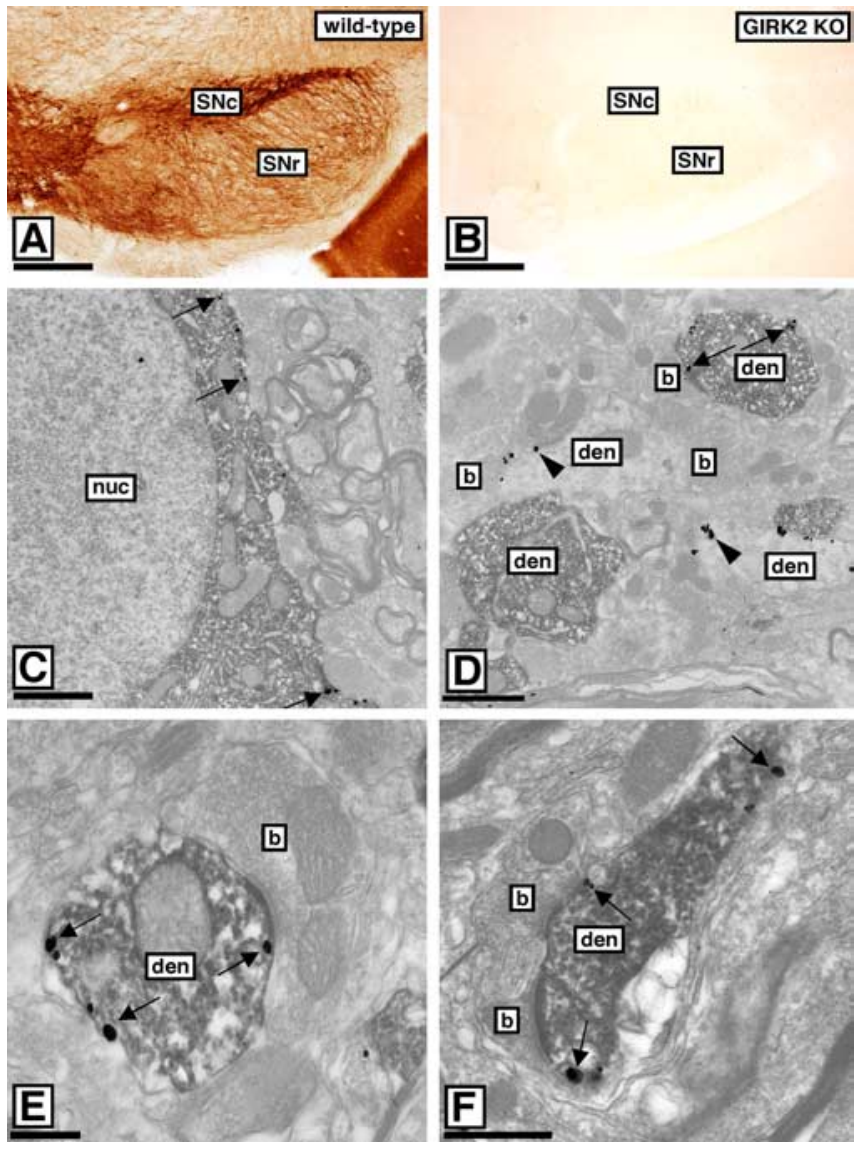

Figure 7. Distribution of GIRK2 in the SNc. A, In WT sections containing the SN, GIRK2 immunoreactivity was most prominent in SNc neuron dendrites found in the SNr. B, No GIRK2 staining was observed in sections from GIRK2 KO mice. C, Colocalization of the GIRK2 subunit and TH in the SNc of WT mice, as revealed using preembedding methods. The peroxidase reaction product (TH immunoreactivity) filled somata and dendritic shafts, whereas immunoparticles (GIRK2 immunoreactivity) were located along the extrasynaptic plasma membrane (arrows). D, Immunoparticles for GIRK2 (arrowheads) were also detected along the extrasynaptic plasma membrane of dendritic shafts immunonegative for $\mathrm{TH}$, likely belonging to GABAergic neurons. $\boldsymbol{E}, \boldsymbol{F}$, Electron micrographs showing colocalization of the GIRK2 and $G A B A_{B(1)}$ in the $S N C$ of WT mice. A peroxidase reaction product $\left(G A B A_{B(1)}\right.$ immunoreactivity) filled dendritic shafts establishing asymmetrical synapses with axon terminals, whereas immunoparticles (GIRK2 immunoreactivity) were located along the extrasynaptic plasma membrane (arrows). b, Bouton; den, dendritic shaft; nuc, nucleus. Scale bars: $\boldsymbol{A}, \boldsymbol{B}, 200 \mu \mathrm{m} ; \boldsymbol{C}-\boldsymbol{F}, 0.2 \mu \mathrm{m}$.

subunit expression patterns in the hippocampus and $\mathrm{SN}$ to assess the relevance of subunit composition to receptor coupling and subcellular distribution. We demonstrated that GIRK channels account for the vast majority of the postsynaptic current triggered by $\mathrm{GABA}_{\mathrm{B}}$ receptor activation in both CA1 pyramidal neurons and DA neurons of the $\mathrm{SNc}$. In the hippocampus, complexes formed by GIRK1 and GIRK2 appear to be the dominant underlying channel, although GIRK3 also makes a minor contribution to current density. GIRK1, GIRK2, GIRK3, and the $\mathrm{GABA}_{\mathrm{B}}$ receptor were found to be variably distributed in lipid rafts, supporting the argument that multiple pools of GIRK channels of distinct subunit composition exist in the CNS. Indeed, we demonstrated that the GIRK channel coupled to the $\mathrm{GABA}_{\mathrm{B}}$ receptor in the SNc DA neurons consists solely of Girk2 gene product(s). As such, our findings support the contention that cellular and subcellular diversity exists with respect to neuronal GIRK channels and provide insight into the relevance of individual subunits to channel function.

The loss of GIRK1 in CA1 neurons had little impact on resid-

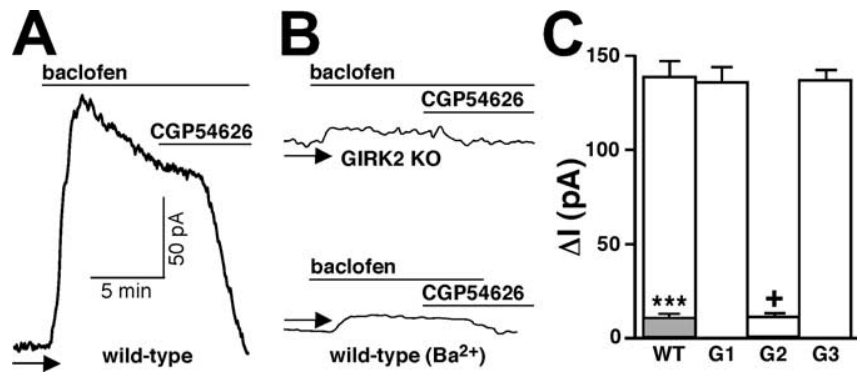

Figure 8. Baclofen-induced current in DA neurons of the SNc from WT and GIRK KO mice. $A$, $B$, Outward currents induced by baclofen $(50 \mu \mathrm{m})$ in SNC DA neurons from WT and GIRK2 KO mice. Currents were reversed with CGP54626 (CGP; $1 \mu \mathrm{M}$ ) and dramatically reduced in the presence of $1 \mathrm{~mm} \mathrm{Ba}^{2+}$. The arrow identifies the zero current levels. $C$, Average peak currents evoked by baclofen in SNC DA neurons from WT ( $n=12)$, GIRK1 (G1; $n=6)$, GIRK2 (G2;n=4), and GIRK3 $(G 3 ; n=7) \mathrm{KO}$ mice. The gray inset shows the mean peak response of WT neurons to baclofen in the presence of $1 \mathrm{~mm} \mathrm{Ba}^{2} .{ }^{+} p<0.05$ versus WT; ${ }^{* * *} p<0.001$ versus control (no barium).

ual GIRK protein levels and subcellular distributions. Nevertheless, the residual GIRK subunits were incapable of coupling effectively to $\mathrm{GABA}_{\mathrm{B}}$ receptors, reminiscent of our previous observations in atrial myocytes from GIRK1 KO mice (Bettahi et al., 2002). We conclude, therefore, that GIRK1 promotes effective coupling between GIRK channels containing this subunit and G-protein-coupled receptors. Our observation that GIRK2 homomultimeric channels couple effectively to $\mathrm{GABA}_{\mathrm{B}}$ receptors in the $\mathrm{SNc}$ indicates, however, that GIRK1 is not required for robust channel-receptor interactions. Observed differences in the coupling to $\mathrm{GABA}_{\mathrm{B}}$ receptors of native GIRK2 homomultimers in SNc DA neurons and residual GIRK channels in GIRK1 KO CA1 neurons argue that distinct mechanisms facilitate effective channel receptor interactions in a cell type-dependent manner.

The inability of residual GIRK2 homomultimeric channels to mediate robust baclofen-evoked current responses in CA1 neurons from GIRK1 KO mice may be explained in several ways. For example, the GIRK channel in the SN was proposed to consist of GIRK2a and GIRK2c subunit isoforms (Wei et al., 1998; Inanobe et al., 1999), and one of these GIRK2 variants may be functionally equivalent to GIRK1. Both of these GIRK2 variants, however, were found in the hippocampus (Leaney, 2003). Alternatively, an unidentified protein(s) may facilitate channel coupling with receptors in a cell type-specific manner. It is also tempting to speculate that GIRK1 promotes the raft association of GIRK channels. In this regard, it is interesting to note that the mature glycosylation of many proteins occurs before their association with lipid rafts (Simons and Ikonen, 1997; Roper et al., 2000; Riddell et al., 2001; Vinson et al., 2003). GIRK1 has a single N-linked glycosylation consensus sequence at residue 119 . In COS-7 cells, GIRK4 and the glycosylation-deficient (N119D) GIRK1 mutant combined to form functional channels with biophysical properties identical to those of the WT GIRK1/GIRK4 channel (Kennedy et al., 1999). Channel activity was evoked, however, with direct application of $\mathrm{G} \beta \gamma$; thus, the impact of the N119D mutation on channel interactions with receptor and endogenous G-proteins was not explored. Although perhaps irrelevant in the context of a non-native environment, mature glycosylation of GIRK1 may be required for the delivery of GIRK1/GIRK2 heteromultimers to specific subcellular compartments and/or for positioning near $\mathrm{GABA}_{\mathrm{B}}$ receptors.

GIRK3 was proposed to target functional neuronal GIRK channels (GIRK1/GIRK2 heteromultimers and GIRK2 homomultimers) to lyzosomal degradation pathways (Ma et al., 2002). 
If this were the primary role for GIRK3, one would predict that the levels and/or activity of residual GIRK channels would be elevated in GIRK3 KO mice. In CA1 neurons from GIRK3 KO mice, however, we failed to detect enhanced baclofen-evoked current. Rather, the concurrent absence of GIRK2 and GIRK3 was necessary to eliminate nearly all of the baclofen-evoked current in these neurons. Furthermore, the levels of residual GIRK1 and GIRK2 were not increased in hippocampal protein samples from GIRK3 KO mice. Indeed, the impact of GIRK2 and/or GIRK3 ablation on the level of residual GIRK1 (particularly on the level of heavily glycosylated GIRK1) is most consistent with a channel-forming role for GIRK3.

Although our observations do not support a trafficking role for GIRK3, GIRK3-containing channels seem to play only a modest role in the postsynaptic inhibitory effects of $\mathrm{GABA}_{\mathrm{B}}$ receptor stimulation. Indeed, baclofen-induced currents in CA1 neurons were only modestly reduced ( $\sim 10 \mathrm{pA})$ with the loss of GIRK3. A similar modest contribution of GIRK3 to opioid-induced current was observed in the locus coeruleus (Torrecilla et al., 2002). Thus, whereas GIRK3 adds to the repertoire of functional GIRK channels in the CNS, it seems likely that we have not as yet identified its primary contribution. GIRK3-containing channels may display preferential coupling to a subset of G-protein-coupled receptors not challenged in this or previous studies. It is also possible that GIRK3-containing channels are preferentially distributed to distal dendrites and/or axonal compartments that make minimal contributions to the whole-cell currents measured in this and previous studies.

Consistent with previous studies (Ponce et al., 1996; Drake et al., 1997; Luscher et al., 1997; Takigawa and Alzheimer, 1999; Chen and Johnston, 2005), we found GIRK1 and GIRK2 primarily in the dendritic compartment. GIRK1 and GIRK2 were found at extrasynaptic or perisynaptic sites of postsynaptic specialization in hippocampal CA1 neurons, reminiscent of the distribution of the $\mathrm{GABA}_{\mathrm{B}}$ receptor (Kulik et al., 2003). Extrasynaptic and perisynaptic $\mathrm{GABA}_{\mathrm{B}}$ receptors are proposed to respond to GABA "spilling over" from synapses during synchronous activity of many inhibitory interneurons (Scanziani, 2000; Nicoll, 2004). Given our data, it seems reasonable to suggest that GIRK channels consisting of GIRK1 and GIRK2 mediate the dominant component of the GABA-mediated postsynaptic inhibition. GIRK channels may also contribute to the inhibitory effects of other receptors. For example, metabotropic glutamate receptor 5 is also found extrasynaptically and perisynaptically in the CA1 neuron dendrites (Lujan et al., 1996), and studies in expression systems have shown that this receptor can couple to GIRK channels (Malherbe et al., 2002). Thus, GIRK channels may serve as a break in the context of elevated glutamate release.

Although the extrasynaptic distributions of GIRK1 and GIRK2 were strikingly similar, only GIRK2 was detected within the synaptic specialization. The absence of GIRK1 in the postsynaptic specialization is additional evidence of the molecular diversity of GIRK channels in the CNS and is consistent with recent observations made in the spinal cord dorsal horn (Marker et al., 2005). Channels within the synaptic specialization are likely either GIRK2 homomultimers or GIRK2/GIRK3 heterotetramers. The distribution of such channels within the synaptic specialization may reflect the presence of a PDZ (postsynaptic density-95/ Discs large/zona occludens-1) interaction motif on one of the GIRK2 splice variants and/or GIRK3 (Inanobe et al., 1999; Hibino et al., 2000; Nehring et al., 2000; Kurachi and Ishii, 2004). At present, the functional significance of GIRK channels within the synaptic specialization is unknown.
Consistent with previous observations (Morishige et al., 1996; Ponce et al., 1996; Marker et al., 2005) but contrary to observations from functional studies (Luscher et al., 1997), we found small but significant presynaptic labeling for GIRK subunits in glutamatergic terminals establishing synapses with CA1 neurons. Presynaptic inhibition is thought to result primarily from the G-protein-dependent suppression of voltage-gated $\mathrm{Ca}^{2+}$ channel activity (Dolphin and Scott, 1986; Scott and Dolphin, 1986; Scholz and Miller, 1991; Tatebayashi and Ogata, 1992; Campbell et al., 1993). Functional studies involving GIRK2 KO mice have not supported a contribution of GIRK channels to presynaptic inhibition (Luscher et al., 1997). It is possible, however, that the resolution of techniques used to sample presynaptic inhibition in GIRK2 KO mice was insufficient to detect a modest contribution of GIRK channels to the suppression of neurotransmitter release. Alternatively, GIRK2 and GIRK3 may assemble to form presynaptic GIRK channels (Grosse et al., 2003), and the simultaneous ablation of both subunits may then be required to significantly affect this putative mechanism of presynaptic inhibition. Examining the potential contribution of GIRK channels to presynaptic inhibition will be facilitated by future studies involving GIRK2/ GIRK3 KO mice.

In summary, we found that the three primary neuronal GIRK subunits assemble to form multiple pools of functional channels that can differ from cell to cell and across subcellular compartments. Furthermore, we present evidence that multiple active processes of signaling compartmentalization facilitate interactions between the $\mathrm{GABA}_{\mathrm{B}}$ receptor and neuronal GIRK channels of defined subunit composition. These observations indicate that it may be possible to use GIRK channel subtype-specific drugs or gene therapy to selectively modulate neuronal excitability, which may prove useful in the contexts of epilepsy, mood disorders, pain, and addiction.

\section{References}

Alvarez FJ, Villalba RM, Zerda R, Schneider SP (2004) Vesicular glutamate transporters in the spinal cord, with special reference to sensory primary afferent synapses. J Comp Neurol 472:257-280.

Barr J, Van Bockstaele EJ (2005) Vesicular glutamate transporter-1 colocalizes with endogenous opioid peptides in axon terminals of the rat locus coeruleus. Anat Rec A Discov Mol Cell Evol Biol 284:466-474.

Bartsch U, Bartsch S, Dorries U, Schachner M (1992) Immunohistological localization of tenascin in the developing and lesioned adult mouse optic nerve. Eur J Neurosci 4:338-352.

Bettahi I, Marker CL, Roman MI, Wickman K (2002) Contribution of the Kir3.1 subunit to the muscarinic-gated atrial potassium channel $\mathrm{I}_{\mathrm{KACh}}$. J Biol Chem 277:48282-48288.

Blednov YA, Stoffel M, Chang SR, Harris RA (2001) GIRK2 deficient mice. Evidence for hyperactivity and reduced anxiety. Physiol Behav 74:109-117.

Blednov YA, Stoffel M, Alva H, Harris RA (2003) A pervasive mechanism for analgesia: activation of GIRK2 channels. Proc Natl Acad Sci USA 100:277-282.

Campbell V, Berrow N, Dolphin AC (1993) GABAB receptor modulation of $\mathrm{Ca}^{2+}$ currents in rat sensory neurones by the $\mathrm{G}$ protein $\mathrm{G}(0)$ : antisense oligonucleotide studies. J Physiol (Lond) 470:1-11.

Chen SC, Ehrhard P, Goldowitz D, Smeyne RJ (1997) Developmental expression of the GIRK family of inward rectifying potassium channels: implications for abnormalities in the weaver mutant mouse. Brain Res 778:251-264.

Chen X, Johnston D (2005) Constitutively active G-protein-gated inwardly rectifying $\mathrm{K}^{+}$channels in dendrites of hippocampal CA1 pyramidal neurons. J Neurosci 25:3787-3792.

Cruz HG, Ivanova T, Lunn ML, Stoffel M, Slesinger PA, Luscher C (2004) Bi-directional effects of $\mathrm{GABA}(\mathrm{B})$ receptor agonists on the mesolimbic dopamine system. Nat Neurosci 7:153-159.

Delling M, Wischmeyer E, Dityatev A, Sytnyk V, Veh RW, Karschin A, 
Schachner M (2002) The neural cell adhesion molecule regulates cellsurface delivery of G-protein-activated inwardly rectifying potassium channels via lipid rafts. J Neurosci 22:7154-7164.

Dolphin AC, Scott RH (1986) Inhibition of calcium currents in cultured rat dorsal root ganglion neurones by (-)-baclofen. Br J Pharmacol $88: 213-220$.

Drake CT, Bausch SB, Milner TA, Chavkin C (1997) GIRK1 immunoreactivity is present predominantly in dendrites, dendritic spines, and somata in the CAl region of the hippocampus. Proc Natl Acad Sci USA 94:1007-1012.

Fritschy JM, Meskenaite V, Weinmann O, Honer M, Benke D, Mohler H (1999) $\mathrm{GABA}_{\mathrm{B}}$-receptor splice variants GBla and GB1b in rat brain: developmental regulation, cellular distribution and extrasynaptic localization. Eur J Neurosci 11:761-768.

Grace AA, Onn SP (1989) Morphology and electrophysiological properties of immunocytochemically identified rat dopamine neurons recorded in vitro. J Neurosci 9:3463-3481.

Grosse G, Eulitz D, Thiele T, Pahner I, Schroter S, Takamori S, Grosse J, Wickman K, Tapp R, Veh RW, Ottersen OP, Ahnert-Hilger G (2003) Axonal sorting of Kir3.3 defines a GABA-containing neuron in the CA3 region of rodent hippocampus. Mol Cell Neurosci 24:709-724.

Hibino H, Inanobe A, Tanemoto M, Fujita A, Doi K, Kubo T, Hata Y, Takai Y, Kurachi Y (2000) Anchoring proteins confer G protein sensitivity to an inward-rectifier $\mathrm{K}^{+}$channel through the GK domain. EMBO J 19:78 - 83 .

Inanobe A, Ito H, Ito M, Hosoya Y, Kurachi Y (1995) Immunological and physical characterization of the brain $\mathrm{G}$ protein- gated muscarinic potassium channel. Biochem Biophys Res Commun 217:1238-1244.

Inanobe A, Yoshimoto Y, Horio Y, Morishige KI, Hibino H, Matsumoto S, Tokunaga Y, Maeda T, Hata Y, Takai Y, Kurachi Y (1999) Characterization of G-protein-gated $\mathrm{K}^{+}$channels composed of Kir3.2 subunits in dopaminergic neurons of the substantia nigra. J Neurosci 19:1006-1017.

Jelacic TM, Sims SM, Clapham DE (1999) Functional expression and characterization of G-protein-gated inwardly rectifying $\mathrm{K}^{+}$channels containing GIRK3. J Membr Biol 169:123-129.

Jelacic TM, Kennedy ME, Wickman K, Clapham DE (2000) Functional and biochemical evidence for G-protein-gated inwardly rectifying $\mathrm{K}^{+}$ (GIRK) channels composed of GIRK2 and GIRK3. J Biol Chem 275:36211-36216.

Karschin C, Dissmann E, Stuhmer W, Karschin A (1996) IRK(1-3) and GIRK(1-4) inwardly rectifying $\mathrm{K}^{+}$channel mRNAs are differentially expressed in the adult rat brain. J Neurosci 16:3559-3570.

Kennedy ME, Nemec J, Clapham DE (1996) Localization and interaction of epitope-tagged GIRK1 and CIR inward rectifier $\mathrm{K}^{+}$channel subunits. Neuropharmacology 35:831-839.

Kennedy ME, Nemec J, Corey S, Wickman K, Clapham DE (1999) GIRK4 confers appropriate processing and cell surface localization to G-proteingated potassium channels. J Biol Chem 274:2571-2582.

Kobayashi T, Ikeda K, Ichikawa T, Abe S, Togashi S, Kumanishi T (1995) Molecular cloning of a mouse G-protein-activated $\mathrm{K}^{+}$channel (mGIRK1) and distinct distributions of three GIRK (GIRK1, 2 and 3) mRNAs in mouse brain. Biochem Biophys Res Commun 208:1166-1173.

Kofuji P, Davidson N, Lester HA (1995) Evidence that neuronal G-proteingated inwardly rectifying $\mathrm{K}^{+}$channels are activated by $\mathrm{G}$ beta gamma subunits and function as heteromultimers. Proc Natl Acad Sci USA 92:6542-6546.

Krapivinsky G, Gordon EA, Wickman K, Velimirovic B, Krapivinsky L, Clapham DE (1995a) The G-protein-gated atrial $\mathrm{K}^{+}$channel $\mathrm{I}_{\mathrm{KACh}}$ is a heteromultimer of two inwardly rectifying $\mathrm{K}^{+}$-channel proteins. Nature 374:135-141.

Krapivinsky G, Krapivinsky L, Velimirovic B, Wickman K, Navarro B, Clapham DE (1995b) The cardiac inward rectifier $\mathrm{K}^{+}$channel subunit, CIR, does not comprise the ATP-sensitive $\mathrm{K}^{+}$channel, $\mathrm{I}_{\mathrm{KATP}}$. J Biol Chem 270:28777-28779.

Kulik A, Vida I, Lujan R, Haas CA, Lopez-Bendito G, Shigemoto R, Frotscher M (2003) Subcellular localization of metabotropic GABA(B) receptor subunits $\mathrm{GABA}(\mathrm{B} 1 \mathrm{a} / \mathrm{b})$ and $\mathrm{GABA}(\mathrm{B} 2)$ in the rat hippocampus. J Neurosci 23:11026-11035.

Kurachi Y, Ishii M (2004) Cell signal control of the G protein-gated potassium channel and its subcellular localization. J Physiol (Lond) 554:285-294.

Lacey MG, Mercuri NB, North RA (1989) Two cell types in rat substantia nigra zona compacta distinguished by membrane properties and the actions of dopamine and opioids. J Neurosci 9:1233-1241.

Leaney JL (2003) Contribution of Kir3.1, Kir3.2A and Kir3.2C subunits to native $\mathrm{G}$ protein-gated inwardly rectifying potassium currents in cultured hippocampal neurons. Eur J Neurosci 18:2110-2118.

Lesage F, Guillemare E, Fink M, Duprat F, Heurteaux C, Fosset M, Romey G, Barhanin J, Lazdunski M (1995) Molecular properties of neuronal G-protein-activated inwardly rectifying $\mathrm{K}^{+}$channels. J Biol Chem 270:28660-28667.

Li JL, Fujiyama F, Kaneko T, Mizuno N (2003) Expression of vesicular glutamate transporters, VGluT1 and VGluT2, in axon terminals of nociceptive primary afferent fibers in the superficial layers of the medullary and spinal dorsal horns of the rat. J Comp Neurol 457:236-249.

Liao YJ, Jan YN, Jan LY (1996) Heteromultimerization of G-protein-gated inwardly rectifying $\mathrm{K}^{+}$channel proteins GIRK1 and GIRK2 and their altered expression in weaver brain. J Neurosci 16:7137-7150.

Liss B, Neu A, Roeper J (1999) The weaver mouse gain-of-function phenotype of dopaminergic midbrain neurons is determined by coactivation of wvGirk2 and K-ATP channels. J Neurosci 19:8839-8848.

Lopez-Bendito G, Shigemoto R, Kulik A, Paulsen O, Fairen A, Lujan R (2002) Expression and distribution of metabotropic GABA receptor subtypes GABABR1 and GABABR2 during rat neocortical development. Eur J Neurosci 15:1766-1778.

Lujan R, Nusser Z, Roberts JD, Shigemoto R, Somogyi P (1996) Perisynaptic location of metabotropic glutamate receptors mGluR1 and mGluR5 on dendrites and dendritic spines in the rat hippocampus. Eur J Neurosci 8:1488-1500.

Luscher C, Jan LY, Stoffel M, Malenka RC, Nicoll RA (1997) G proteincoupled inwardly rectifying $\mathrm{K}^{+}$channels (GIRKs) mediate postsynaptic but not presynaptic transmitter actions in hippocampal neurons. Neuron 19:687-695.

Ma D, Zerangue N, Raab-Graham K, Fried SR, Jan YN, Jan LY (2002) Diverse trafficking patterns due to multiple traffic motifs in $G$ proteinactivated inwardly rectifying potassium channels from brain and heart. Neuron 33:715-729.

Malherbe P, Kew JN, Richards JG, Knoflach F, Kratzeisen C, Zenner MT, Faull RL, Kemp JA, Mutel V (2002) Identification and characterization of a novel splice variant of the metabotropic glutamate receptor 5 gene in human hippocampus and cerebellum. Brain Res Mol Brain Res 109:168-178.

Malitschek B, Ruegg D, Heid J, Kaupmann K, Bittiger H, Frostl W, Bettler B, Kuhn R (1998) Developmental changes of agonist affinity at GABABR1 receptor variants in rat brain. Mol Cell Neurosci 12:56-64.

Marker CL, Cintora SC, Roman MI, Stoffel M, Wickman K (2002) Hyperalgesia and blunted morphine analgesia in $\mathrm{G}$ protein-gated potassium channel subunit knockout mice. NeuroReport 13:2509-2513.

Marker CL, Stoffel M, Wickman K (2004) Spinal G-protein-gated K ${ }^{+}$channels formed by GIRK1 and GIRK2 subunits modulate thermal nociception and contribute to morphine analgesia. J Neurosci 24:2806-2812.

Marker C, Lujan R, Loh H, Wickman K (2005) Spinal G protein-gated potassium channels contribute in a dose-dependent manner to the analgesic effect of mu and delta but not kappa opioids. J Neurosci 25:3551-3559.

Mitrovic I, Margeta-Mitrovic M, Bader S, Stoffel M, Jan LY, Basbaum AI (2003) Contribution of GIRK2-mediated postsynaptic signaling to opiate and alpha 2-adrenergic analgesia and analgesic sex differences. Proc Natl Acad Sci USA 100:271-276.

Morgan AD, Carroll ME, Loth AK, Stoffel M, Wickman K (2003) Decreased cocaine self-administration in Kir3 potassium channel subunit knockout mice. Neuropsychopharmacology 28:932-938.

Morishige KI, Inanobe A, Takahashi N, Yoshimoto Y, Kurachi H, Miyake A, Tokunaga Y, Maeda T, Kurachi Y (1996) G protein-gated $\mathrm{K}^{+}$channel (GIRK1) protein is expressed presynaptically in the paraventricular nucleus of the hypothalamus. Biochem Biophys Res Commun 220:300-305.

Murer G, Adelbrecht C, Lauritzen I, Lesage F, Lazdunski M, Agid Y, RaismanVozari R (1997) An immunocytochemical study on the distribution of two G-protein-gated inward rectifier potassium channels (GIRK2 and GIRK4) in the adult rat brain. Neuroscience 80:345-357.

Mutneja M, Berton F, Suen KF, Luscher C, Slesinger PA (2005) Endogenous RGS proteins enhance acute desensitization of GABA(B) receptoractivated GIRK currents in HEK-293T cells. Pflügers Arch 450:61-73.

Nehring RB, Wischmeyer E, Doring F, Veh RW, Sheng M, Karschin A (2000) 
Neuronal inwardly rectifying $\mathrm{K}^{+}$channels differentially couple to PDZ proteins of the PSD-95/SAP90 family. J Neurosci 20:156-162.

Nicoll RA (2004) My close encounter with GABA(B) receptors. Biochem Pharmacol 68:1667-1674.

North A (1989) Drug receptors and the inhibition of nerve cells. Br J Pharmacol 98:13-28.

Paxinos G, Franklin K (2003) The mouse brain in stereotaxic coordinates. San Diego: Academic.

Ponce A, Bueno E, Kentros C, Vega-Saenz de Miera E, Chow A, Hillman D, Chen S, Zhu L, Wu MB, Wu X, Rudy B, Thornhill WB (1996) G-protein-gated inward rectifier $\mathrm{K}^{+}$channel proteins (GIRK1) are present in the soma and dendrites as well as in nerve terminals of specific neurons in the brain. J Neurosci 16:1990-2001.

Riddell DR, Christie G, Hussain I, Dingwall C (2001) Compartmentalization of beta-secretase (Asp2) into low-buoyant density, noncaveolar lipid rafts. Curr Biol 11:1288-1293.

Roper K, Corbeil D, Huttner WB (2000) Retention of prominin in microvilli reveals distinct cholesterol-based lipid micro-domains in the apical plasma membrane. Nat Cell Biol 2:582-592.

Scanziani M (2000) GABA spillover activates postsynaptic GABA(B) receptors to control rhythmic hippocampal activity. Neuron 25:673-681.

Schein JC, Hunter DD, Roffler-Tarlov S (1998) Girk2 expression in the ventral midbrain, cerebellum, and olfactory bulb and its relationship to the murine mutation weaver. Dev Biol 204:432-450.

Scholz KP, Miller RJ (1991) GABA-B receptor-mediated inhibition of $\mathrm{Ca}^{2+}$ currents and synaptic transmission in cultured rat hippocampal neurons. J Physiol (Lond) 444:669-686.

Scott RH, Dolphin AC (1986) Regulation of calcium currents by a GTP analogue: potentiation of $(-)$-baclofen-mediated inhibition. Neurosci Lett 69:59-64.

Signorini S, Liao YJ, Duncan SA, Jan LY, Stoffel M (1997) Normal cerebellar development but susceptibility to seizures in mice lacking $\mathrm{G}$ protein- coupled, inwardly rectifying $\mathrm{K}^{+}$channel GIRK2. Proc Natl Acad Sci USA 94:923-927.

Simons K, Ikonen E (1997) Functional rafts in cell membranes. Nature 387:569-572.

Slesinger P, Stoffel M, Jan Y, Jan L (1997) Defective $\gamma$-aminobutyric acid type $\mathrm{B}$ receptor-activated inwardly rectifying $\mathrm{K}^{+}$currents in cerebellar granule cells isolated from weaver and Girk2 null mutant mice. Proc Natl Acad Sci USA 94:12210-12217.

Takigawa T, Alzheimer C (1999) G protein-activated inwardly rectifying $\mathrm{K}^{+}$(GIRK) currents in dendrites of rat neocortical pyramidal cells. J Physiol (Lond) 517:385-390.

Tatebayashi H, Ogata N (1992) GABAB-mediated modulation of the voltage-gated $\mathrm{Ca}^{2+}$ channels. Gen Pharmacol 23:309-316.

Todd AJ, Hughes DI, Polgar E, Nagy GG, Mackie M, Ottersen OP, Maxwell DJ (2003) The expression of vesicular glutamate transporters VGLUT1 and VGLUT2 in neurochemically defined axonal populations in the rat spinal cord with emphasis on the dorsal horn. Eur J Neurosci 17:13-27.

Torrecilla M, Marker CL, Cintora SC, Stoffel M, Williams JT, Wickman K (2002) G-protein-gated potassium channels containing Kir3.2 and Kir3.3 subunits mediate the acute inhibitory effects of opioids on locus ceruleus neurons. J Neurosci 22:4328-4334.

Vinson M, Rausch O, Maycox PR, Prinjha RK, Chapman D, Morrow R, Harper AJ, Dingwall C, Walsh FS, Burbidge SA, Riddell DR (2003) Lipid rafts mediate the interaction between myelin-associated glycoprotein (MAG) on myelin and MAG-receptors on neurons. Mol Cell Neurosci 22:344-352.

Wei J, Hodes ME, Piva R, Feng Y, Wang Y, Ghetti B, Dlouhy SR (1998) Characterization of murine Girk2 transcript isoforms: structure and differential expression. Genomics 51:379-390.

Wischmeyer E, Doring F, Wischmeyer E, Spauschus A, Thomzig A, Veh R, Karschin A (1997) Subunit interactions in the assembly of neuronal Kir3.0 inwardly rectifying $\mathrm{K}^{+}$channels. Mol Cell Neurosci 9:194-206. 